\title{
The Need for the Development of Indonesian Language Syntax Teaching Materials Based on STEAM Approach
}

\author{
Reni Kusmiarti ${ }^{1, *}$, Johanes Sapri ${ }^{2}$ and Ria Ariesta ${ }^{2}$ \\ ${ }^{I}$ Faculty of Teacher Training and Education, University of Muhammadiyah Bengkulu \\ ${ }^{2}$ Faculty of Teacher Training and Education, University of Bengkulu \\ *Corresponding author.Email: renikusmiarti@umb.ac.id
}

\begin{abstract}
The purpose of this research is to analyze the need for the development of Indonesian syntactic teaching materials based on Science, Technology, Engineering, Art, and Mathematic (STEAM) approach. This qualitative descriptive research has 105 Indonesian Literature and Language Education students as research subjects from Muhammadiyah Bengkulu University and Bengkulu University. Data collection in this study was conducted online using a questionnaire based on indicators of lack, necessities, and wants. The results of the questionnaire indicate that $53 \%$ of students stated that there are still many shortcomings in the implementation of syntactic learning, $93.28 \%$ of students stated that the development of teaching materials in the eye is still needed, $92.78 \%$ of students to want a change in Indonesian language syntax learning with an approach based on STEAM. Based on the research results, it is very necessary to develop STEAM-based teaching materials to support the improvement of student competencies in Indonesian syntactic courses.
\end{abstract}

Keywords: Needs analysis, teaching materials, Indonesian syntax, STEAM.

\section{INTRODUCTION}

In the industrial era 4.0, information technology is the basis of human life. In the field of education, especially tertiary institutions, the learning process and practice cannot be separated from the use of technology, including in syntactic learning activities for students in the Indonesian Language and Literature Education Study Program. Competencies needed in the 21 st century are most importantly able to carry out $4 \mathrm{C}$, namely the ability to think critically, creativity, collaboration, and communication and have higher order thinking skills (HOTS) [1]. The syntax learning process for students is expected to be able to refer to the four characters of $21^{\text {st }}$ century learning, namely critical thinking and problem solving, creativity and innovation, collaboration, communication. Syntax learning material is not material that is memorizing and understanding, but material that is complex in nature that requires critical thinking skills. The demand for student-centered learning is a necessity. Students must have choices about the material being studied to have the same competence. Syntax learning must be shifted to multimedia based. Related to the syntax course, several aspects of the learning process that must be done to face the challenges in the era of 4.0, the era of computers and digital technology are learning and technology, learning to construct meaning, active learning, accountability learning.

The achievement of syntactic learning objectives has not led to demands in the era of 4.0 and 21 st century learning. The facts show that in the Indonesian Language and Literature Education Study Program, Muhammadiyah University of Bengkulu, syntactic learning has not achieved satisfactory results. The results of interviews with lecturers in the syntactic course of the Indonesian Language and Literature Education study program, FKIP Muhammadiyah Bengkulu University, were less than $60 \%$ of the students' syntactic learning outcomes achieved the expected competence. The achievement was $25 \%$ got an A, 30\% got a B grade and $45 \%$ got a C and D. The results of interviews with students who had taken courses complained about the complexity of syntactic concepts so that students' mastery of syntactic concepts was still low. Low student participation during the syntactic learning process is occured. The implementation of syntactic learning also has not led students to think critically. Lecturers who teach syntax have not used teaching materials in accordance with the requirements of ideal teaching materials; the teaching materials used have not paid attention to the accuracy of the content and the accuracy of the coverage. 
A previous study reported that most of the students experience difficulties in understanding syntactic concepts, values obtained by students are not satisfactory, the average score is low (C). Based on the pre-test result, the content of which is related to syntactic concepts, it was found that $36.20 \%$ of students' mastery of syntactic concepts was still very low because it had not reached $60 \%$ as an indicator of the achievement of learning objectives [1].

Furthermore, a study [2] reported that lecturers still use teaching material that only focuses on four aspects, namely (1) knowledge of syntax, (2) phrase preparation, (3) clause preparation, and (4) sentence arrangement. The four aspects which are the main material in this syntax course are not arranged based on a need analysis in the field. Lecturers who teach Syntax courses also do not use self-made teaching materials; they use available books that cannot be used as materials that meet the demands of competency achievement. Moreover, students' mastery of syntactic concepts was still low, syntactic learning had not achieved satisfactory results, student scores during UTS and UAS were still low, student participation during the learning process was low [3]. One of the things that make the value of the syntax course less satisfying is the teaching materials that don't foster interest in reading.

Related to the teaching materials T. Helda and D. Ramadhanti analyzed and validated Problem Based Learning (PBL) syntactic learning tools to overcome student difficulties in understanding syntactic concepts and the syntactic learning process that has not gone well [4]. Furthermore, T. Maharani and ES Astuti in a study said that syntactic learning still experienced problems in achieving the targeted learning objectives, namely still not being able to describe and analyze the position of sentence functions, still confused in distinguishing objects from complements, ability to communicate, cooperate, critical thinking, and students' creative thinking is still not maximally developed, the teacher has limitations on one of the learning components, namely teaching materials / materials [5].

Knowledge and syntactic skills as a level of grammar in the context of learning Indonesian are very important for students and this ability is one that students must have. Regarding the form of language, syntax is as one of the linguistic levels of studying, studying sentences. Mastery of the Indonesian language syntax is one of the absolute requirements for mastering a broader language level. Syntax courses are essential language studies and must be mastered by prospective teachers in the Indonesian Language Education Study Program, because Indonesian language teachers must have competences related to sentence science. This subject can be said to be the basis for mastering grammar at a higher level.

According to Supriyadi, syntax needs to be studied because this science discusses sentence structure which is the smallest complete unit of language. Syntax relates to other language elements that are related to sentence-forming elements, including phonemes, words, intonation, silence, and contour [6]. Meanwhile, according to Parera, syntax is very important to learn because the basic competence of a language syntax will be the starting point and starting point for researching unique and interesting language phenomena at the syntactic level of a language [7]. This is reinforced by Miller's opinion that syntax is important to learn because without syntax, humans will not be able to construct complex messages in conveying information about complex situations [8]. Meanwhile, according to Suherdi, it begins with grammar learning which includes syntax, language education is a necessity for national excellence. In line with that, language skills are an important asset in learning [9].

Teaching materials are one of the factors that can generate students' internal motivation to learn. Teaching materials that are designed completely will affect the learning atmosphere, and teaching competencies is more focused, so that the learning process becomes more optimal and can improve student learning achievement. According to Eriyanti, teaching materials play a very important role in facilitating learning activities in developing students' knowledge, thinking skills, critical and creative abilities [10].

Regarding the syntax course, in the industrial era 4.0, syntactic teaching materials must answer the needs of students by strengthening the potential development of each student. It is hoped that Indonesian Language and Literature lecturers will be able to provide the skills needed by students. The learning process must refer to the character of the $21 \mathrm{st}$ century, namely critical thinking and problem solving, creative and innovative, collaborative and communicative.

Starting from the above thinking, the researchers want to examine the needs of Indonesian Language and Literature Education students in Bengkulu for teaching materials based on Science, Technology, Engineering, Arts and Mathematic (STEAM). STEAM is an integrated learning approach that encourages students to think more broadly about realworld problems and supports meaningful learning experiences and problem solving. STEAM is also an applied learning method that uses an inter-science 
approach. This is reinforced by the opinion of Wijaya, et al, who said that the learning approach of Science, Technology, Engineering, Arts, and Mathematics (STEAM) is an integration of various disciplines, namely science, technology, engineering, art and mathematics which are in one unified learning approach [10]. The same thing was stated by Nurhikmayati that STEAM is a meta-discipline that integrates science, technology, engineering, arts and mathematics into an integrated approach that can be implemented in learning at every level of education [11]. G. Yakman and H. Lee also stated STEAM as an innovative integrated convergence education, guiding the development of educational programs [12]. G. Özkan and U. Topsakal in his research suggests that STEAM is taught by integrating the fields of science, mathematics, engineering, art and technology in a holistic manner and helps actualize student learning in terms of concepts, principles, and actions related to science classes [13].

Students with the STEAM approach are expected to be guided in their mindset to be problem solvers, logical thinking, technology literate and able to connect the STEAM approach to the world of work. and can explore the potential that is in him. STEAMbased learning will form the character of students who are able to recognize a concept or knowledge (science) and apply that knowledge with the skills (technology) that are mastered to create or design a method (Engineering) with analysis and based on mathematical data calculations (Mathematic) in order to obtain solution for solving a problem. STEAM requires students how to solve problems, think creatively to solve these problems, think critically to solve problems and be able to create new products. STEAM also aims to prepare students to compete and be ready to work in their chosen field.

This study examines the analysis of the needs of STEAM-based Indonesian syntactic teaching materials with the indicator items Lack, Necessities, and Want. The aim is to describe the various information that can be collected in the needs analysis, namely what is needed, what are the shortcomings, and what students want in learning Indonesian syntax, the analysis of the needs for Indonesian syntactic teaching materials is intended as a reference in developing Indonesian language syntax learning based on Science, Technology, Engineering, Art, and Mathematic (STEAM).

\section{RESEARCH METHODS}

This research was conducted using a qualitative descriptive method with the aim of describing the needs of students for STEAM-based Indonesian Syntax teaching materials. The research subjects were 105 students of the Indonesian Language and Literature Education Study Program from Bengkulu University and Muhammadiyah Bengkulu University who had taken syntactic courses. The data collection technique used is a questionnaire to collect data about student needs for STEAM-based Indonesian syntax teaching materials. The resulting data are in the form of qualitative and quantitative data. The data is analyzed descriptively by systematically arranging the data, organizing the data into categories, synthesizing, arranging according to patterns and drawing conclusions in a narrative.

\section{RESULTS AND DISCUSSION}

\subsection{Research Results}

This needs analysis was carried out to gather information about student needs for STEAM-based Indonesian syntactic teaching materials. This is intended to design Indonesian syntactic learning and to find out the difference between the desired conditions and existing conditions, gather information about gaps and determine priorities of these gaps. This needs analysis is also intended to determine whether the development of STEAM-based Indonesian syntactic teaching materials is the right solution in overcoming learning problems. Language curiculum design divides needs into target needs which include (1) what needs are needed by students, (2) what students do not have, (3) what Wants (wants) are students want to learn [14].

The results of the research on the analysis of the needs of Indonesian syntactic teaching materials based on Science, Technology, Engineering, Art, and Mathematics (STEAM) refer to the opinion of Macalister (Necessities, lack, from Wants). Based on data collection provided to 105 students of the Muhammadiyah University of Bengkulu and Bengkulu University and the results of data analysis, it showed that in the Lack category on average $48.0 \%$ of students agreed, 5.0\% strongly agreed, $43.0 \%$ disagreed and $4.0 \%$ totally disagree. From the average percentage of the Lack category, it shows that $53 \%$ of students state that the Indonesian syntactic learning method currently used has many shortcomings. Necessities category averaged $68.08 \%$ of students agreed, 25.5\% strongly agreed, 6.4\% disagreed and 0.32 expressed strongly disagree. The percentage of the necesities category shows that $94 \%$ of students state that the development of teaching materials in syntactic courses is a necessity for students. In the Wants category, an average of $73.27 \%$ of students 
agreed, $19.51 \%$ strongly agreed, and $7.22 \%$. The percentage of the wants category shows that $92.78 \%$ of students want the development of Science, Technology, Engineering, Art, and Mathematic (STEAM) based syntactic teaching materials. The results of the respondents' answers to the three categories of needs analysis can be seen in Figure 1. as follows:

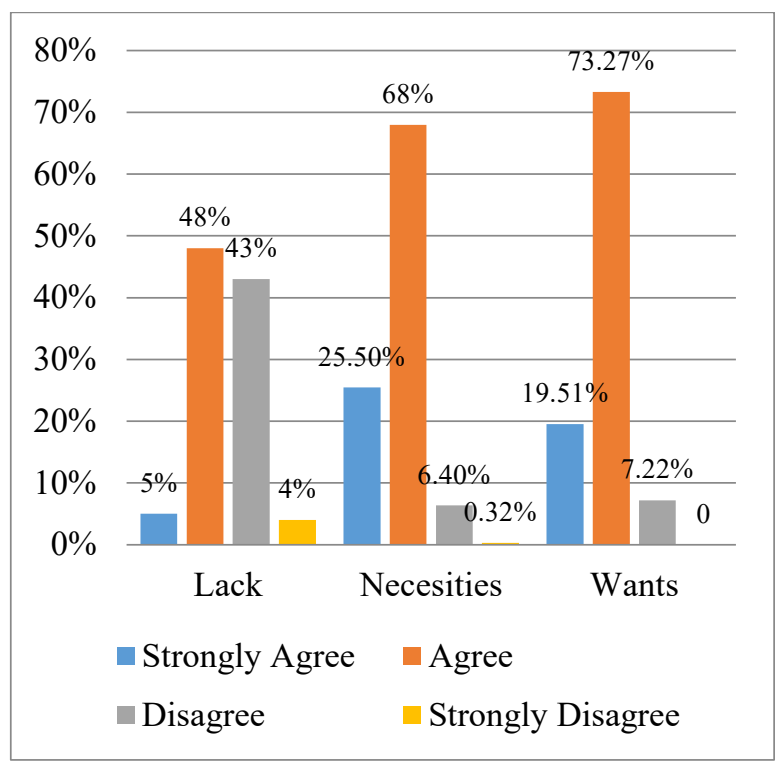

Figure 1. Questionnaire Results Analysis of Syntax Teaching Materials Needs with the STEAM Approach

\subsubsection{Lack}

Needs analysis in the Lack (Deficiency) category to analyze learning problems and constraints in Indonesian syntax courses that occur in current conditions before the implementation of the new method that will be designed, namely the STEAMbased approach. Based on the results of the questionnaire in the lack category, the average student agrees $48.0 \%, 5.0 \%$ strongly agrees. From the percentage of this questionnaire, if viewed as agree and strongly agree, the percentage is $53 \%$, meaning that more than half of the students stated that the Indonesian language syntax learning which is currently being implemented still has many shortcomings.

The shortcomings of learning syntax in Indonesian can be seen from as many as $60.6 \%$ of students stated that syntactic material is difficult to understand. This is according to $65.7 \%$ of students because there are no teaching materials that meet the needs of students, $53.3 \%$ of students state that the teaching materials used are not collaborative and form critical thinking, and $61.4 \%$ of students state that syntax does not have cross-connection disciplines containing Science, Technology, Engineering, Art and mathematics. In addition, $41 \%$ of students stated that lecturers had not been maximal in providing syntactic learning in terms of analyzing syntactic aspects.

\subsubsection{Necessities}

Analysis of needs in the necesities category is determined by the demands of the desired situation and what students must know in order to function it effectively in the desired situation. Based on the results of the questionnaire in the necesities category, the average student agrees $68.08 \%$, strongly agrees $25.2 \%$, disagrees $6.4 \%$ and strongly disagrees $0.32 \%$. From the percentage of this questionnaire $93.28 \%$ of students agree that the development of teaching materials in syntactic courses is a necessity.

There are $94.3 \%$ of students stated that it is necessary to have teaching materials that are better than the teaching materials used today, because syntactic teaching materials need to be adjusted to meet the learning and student needs. According to $91.4 \%$ of students, Indonesian syntactic teaching materials must contain material on the concept of phrases, types and relationships between phrases and phrase arrangement. Not only that, as many as $79 \%$ of students also stated that teaching materials needed to contain concept material, categories and classification of clauses and clause analysis. Teaching materials containing concept material, categories and classification of clauses and clause analysis are also needed in making good sentences according to $94.2 \%$ of students, then $94.3 \%$ of students stated that sentence material, types, and sentence arrangement in teaching materials are also needed so that can independently analyze sentences with logical, critical, systematic thinking.

In addition to teaching materials, $97.2 \%$ of students stated that the use of good language in conveying learning is also very necessary in order to facilitate the readability of messages in understanding syntactic material, where $81.9 \%$ stated that the use of language needs to be adjusted to the intellectual and emotional development of students.

Another factor that is needed in addition to teaching materials and the use of good language in its delivery is the use of technology in the syntactic learning process. According to $92.4 \%$ of students the use of technology is needed in order to facilitate the learning process and accelerate the transfer of knowledge, especially in syntactic courses, where as many as $90.7 \%$ of students stated that in the syntactic learning process, a scientific thinking process and the 
application of new technology in its implementation is needed.

\subsubsection{Wants}

Analysis of needs in the wants category aims to fulfill students' desires to realize what students feel. Based on the results of the questionnaire, an average of $73.27 \%$ agreed, $19.51 \%$ strongly agreed and as much as $7.22 \%$ disagreed. From the percentage of this questionnaire $92.78 \%$ of students want a change in Indonesian language syntax learning with an approach based on Science, Technology, Engineering, Art, and Mathematic (STEAM). There are $97.1 \%$ of students who want syntactic teaching materials to be studied using a scientific approach (observing, asking questions, collecting and processing information, communicating). Almost all students (99.1\%) want syntax teaching materials to be presented systematically and $86.6 \%$ of students want syntax teaching materials to take advantage of the use of technology (internet, classroom, concept map applications, google form).

The focus of the teaching materials desired in the syntactic course by $76 \%$ of students is the design engineering process when providing learning materials, $98.1 \%$ want it to be focused on developing creative thinking patterns, and $91.4 \%$ want it to be focused on the processes and products of student creativity. Teaching materials in syntactic courses are also expected to be developed by paying attention to ethics and aesthetics as art by $92.4 \%$ of students, can be developed into patterns or regularities related to ideas, processes and student reasoning by $94.3 \%$ of students, and can train thinking logical and systematic. In terms of accuracy, the suitability of the material by $98.1 \%$ of students.

\subsection{Discussion}

The results showed that syntactic learning did not contain science, technology, engineering, art and mathematics (STEAM). The results of the questionnaire most of the students needed Indonesian syntactic teaching materials based on the Science, Technology, Engineering, Arts and Mathematics (STEAM) approach. This can be seen from the students' answers that they need a scientific thinking process and the application of new technology in implementing syntactic learning. Students believe that syntactic teaching materials need to be presented systematically, utilizing the use of technology. Teaching materials in courses, syntax are also expected to be developed by paying attention to ethics and aesthetics as art, developed into patterns or regularities related to ideas, processes and reasoning, can train logical and systematic thinking in terms of accuracy, suitability of material. This is in accordance with Nurhikmayati's opinion that with the STEAM approach, students are guided by their mindset to become problem solvers, think logically, are technology literate and able to explore their potential [11].

Most students need learning Indonesian syntax which can foster their motivation and interest in learning, because this is needed by students to develop themselves to learn better, increase achievement and be more creative. This is in accordance with the opinion of S. Nurhasanah and A. Sobandi who said that interest in learning has a positive and significant effect on learning outcomes, the better student interest in learning the better learning outcomes [15].

These needs and desires are based on the shortcomings of previous Indonesian syntactic learning, namely syntactic material is difficult to understand, there is no teaching material that meets the needs of students, is not yet collaborative and forms critical thinking, does not yet contain science and technology. In this era of industrial revolution 4.0, human resources need technical skills and expertise, namely mastering science and technology. Information technology is the basis of life. Meanwhile, science is based on fulfilling the need to produce innovative and superior human resources in the era of the industrial revolution 4.0 through the use of technology. This is according to [16][17] the application of science in response to human demands for a better life. Science and technology can develop through discovery activities with various forms of innovation and engineering.

\section{CONCLUSION}

Based on the results of the questionnaire, it can be concluded that the results of the analysis of the need for the development of STEAM-based Indonesian syntactic teaching materials on the indicator of lack of $53 \%$ of students stated that the implementation of syntactic learning currently has many shortcomings, $93.28 \%$ of the students need the development of teaching materials in courses syntax and the indicator wants $92.78 \%$ of students want a change in Indonesian language syntax learning with an approach based on Science, Technology, Engineering, Art, and Mathematic (STEAM). Based on the results of the questionnaire, it was concluded that the development of STEAM-based teaching materials was needed to support the improvement of student competence in the Indonesian language syntax subject. 


\section{ACKNOWLEDGMENTS}

The researcher expresses his deepest gratitude to the promoters, co-promotor, and the Indonesian Language and Literature Education Study Program, Muhammadiyah Bengkulu University and Bengkulu University for their support for the implementation of this research.

\section{REFERENCES}

[1] U. Khasanah and H. Herina, "Membangun Karakter Siswa Melalui Literasi Digital dalam Menghadapi Pendidikan Abad 21 (Revolusi Industri 4.0)," in Prosiding Seminar Nasional Program Pascasarjana Universitas Pgri Palembang, 2019, vol. 12, no. 01.

[2] A. Awalludin, S. Subadiyono, and N. Nurhayati, "Pengembangan Buku Teks Sintaksis Program Studi Pendidikan Bahasa, Sastra Indonesia dan Daerah Fakultas Keguruan dan Ilmu Pendidikan Universitas Baturaja," Logat J. Bhs. Indones. Dan Pembelajaran, vol. 6, no. 2, pp. 93-101, 2019.

[3] D. Sutrisna and R. K. Nisya, "Model Pembelajaran Berbasis Riset pada Mata Pelajaran Sintaksis," in Prosiding Seminar Nasional Pendidikan, 2019, pp. 1345-1349.

[4] T. Helda and D. Ramadhanti, "Analisis dan Evaluasi Perangkat pembelajaran Sintaksis Berbasis Problem Based Learning(PBL)," Met. J. Penelit. Bhs., vol. 16, no. 2, p. 285, Jan. 2019, doi: 10.26499/metalingua.v16i2.212.

[5] T. Maharani and E. S. Astuti, "Pemerolehan Bahasa Kedua dan Pengajaran Bahasa dalam Pembelajaran BIPA," J. Bhs. Lingua Sci., vol. 10, no. 1, pp. 121-142, Jun. 2018, doi: 10.21274/1s.2018.10.1.121-142.

[6] Supriyadi, Sintaksis Bahasa Indonesa. Gorontalo: UNG Press, 2014.
[7] Y. D. Parera, Dasar-dasar Analisis Sintaksis. Jakarta: Jakarta: Erlangga, 2009.

[8] J. Miller, Introduction to English syntax. Edinburgh University Press, 2016.

[9] D. Suherdi, Rekonstruksi pendidikan bahasa. Bandung, Indonesia: Celtics Press, 2012.

[10] A. D. Wijaya, N. Karmila, and M. R. Amalia, "Implementasi Pembelajaran Berbasis STEAM (Science, Technology, Engineering, Art, Mathematics) pada Kurikulum Indonesia,” 2015.

[11] I. Nurhikmayati, "Implementasi STEAM Dalam Pembelajaran Matematika," Didact. Math., vol. 1, no. 2, 2019.

[12] G. Yakman and H. Lee, "Exploring the exemplary STEAM education in the US as a practical educational framework for Korea," $J$. Korean Assoc. Sci. Educ., vol. 32, no. 6, pp. 1072-1086, 2012.

[13] G. Özkan and Ü. U. Topsakal, "A STEAM Activity That can Be Used in Science Education." Ulakbilge, 2020, 45, 185-199.

[14] J. Macalister and I. S. P. Nation, Language curriculum design. Routledge, 2019.

[15] S. Nurhasanah and A. Sobandi, "Minat belajar sebagai determinan hasil belajar siswa," $J$. Pendidik. Manaj. Perkantoran JPManper, vol. 1, no. 1, pp. 128-135, 2016.

[16] Y. Yuliati and D. S. Saputra, "Pembelajaran sains di era revolusi industri 4.0," J. Cakrawala Pendas, vol. 5, no. 2, 2019.

[17] Eriyanti, Ribut Wahyu." Pengembangan Bahan Ajar Keterampilan Berbicara Interaktif bagi Mahasiswa." KEMBARA: Jurnal Keilmuan Bahasa, Sastra, dan Pengajarannya, Volume 3, Nomor 1, hlm 98-106, PISSN 2442-7632 EISSN 2442-9287. 2018. 